\title{
THE ROLE OF SOCIAL SCIENCES IN THE UPBRINGING OF A HARMONIOUSLY DEVELOPED GENERATION
}

\author{
Nargiza Zuxridinovna Madaminova
}

PhD, Associate professor, Tashkent State University named after Nizami pedagogical university, Uzbekistan

\section{ABSTRACT}

This article discusses the role and importance of the social sciences in strengthening the ideological immunity of young people against various spiritual threats in the context of globalization, in educating them spiritually.

KEYWORDS:- Social sciences, cultural studies, spirituality, theology. ideological immunity, competence, education, upbringing, global, competitive, specialist, higher education.

\section{INTRODUCTION}

The XXIst century is facing global changes not only in information technology, but also in environmental, economic, spiritual and other areas. Despite such global challenges, every country is trying to maintain its position on the world stage, including the Republic of Uzbekistan. In this regard, the country relies on personnel with high potential, competitiveness to be ranked among the states.

The state educational standard, modern curricula and a number of legal and normative documents developed in accordance with the Law of the Republic of Uzbekistan "On Education" and the Law "On the National Program of Personnel Training" which are socially active and competitive with high intellectual potential and moral qualities have become the basis for staff training.

Also, paragraph 4.4 of the Action Strategy, the development of education and science, the introduction of international standards for assessing the quality of education and training to improve the quality and efficiency of higher education institutions. 5.1. security, religious tolerance in the multinational Republic of Uzbekistan and priorities in the field of interethnic harmony create the necessary conditions for our multinational people to live a decent life and realize their creative potential [1].

One of the urgent tasks is to radically reform the methodology of teaching social sciences and humanities in accordance with international educational standards, to improve the quality and effectiveness of teaching social sciences in pedagogical higher education institutions. This will serve as an important factor in preventing the growing geopolitical, spiritual and religious 
CURRENT RESEARCH JOURNAL OF PEDAGOGICS 2(9): 19-21, September

2021 DOI: https://doi.org/10.37547/pedagogics-crjp-02-09-04

ISSN 2767-3278

(C)2021 Master Journals

\section{Crossref do) 11 Google}

Accepted 15th September, 2021 \& Published 20 ${ }^{\text {th }}$ September, 2021

threats, the formation of healthy beliefs and ideological immunity in youth.

Young people are trained in higher education, general secondary special education, or vocational education, ethical and educational skills in academic lyceums. Therefore, at the stage of higher education, the focus is not only on teaching them general philosophical disciplines such as cultural studies, spirituality and religion, but also on educating a person who truly loves his people and country, who sees his destiny in the future of the country.

The goals are high and relevant, but to achieve them, measures to address important issues such as the implementation of pedagogical and methodological aspects of the use of modern pedagogical technologies to improve the system of teaching social sciences are identified:

First, to develop and determine the impact of methodological recommendations that protect against the negative impact of habits, ideas and approaches that negatively affect the worldview, moral consciousness and social activity of young people in the context of information and communication technologies and globalizatrainin.

Second, determination of the role of social sciences in the training of students of pedagogical higher education institutions, specialists with a modern level of moral and spiritual culture in accordance with the requirements of tomorrow;

improvement of theoretical and practical tasks of science teaching;

Third, Improving the scientific basis, forms and mechanisms of the system of teaching social sciences in pedagogical higher education institutions;

Fourth, Pedagogy requires the study of the use of modern pedagogical technologies and methods in the system of teaching social sciences in higher education institutions, the widespread introduction of the results into practice;

Fifth, the creation and implementation of didactic and organizational methodological support for improving the system of teaching social sciences in pedagogical higher education institutions;

Sixth, Creating a theoretical and methodological model of these issues, monitoring the criteria and ways of use is an important scientific, theoretical and practical task.

The eternal goal of the social sciences is to adapt to the existing social being, which has a positive effect on the formation of man as a person, to create a social environment in society, that is, a microenvironment. In this regard, there are a number of sciences and their components, such as philosophy, history, sociology, culturology and theology. Each of the social sciences and humanities has a role to play in the development of society and in solving the problems that hinder it, but in solving some problems it is possible to achieve a higher result than their interdependence.

One of the most important conditions for strengthening independence, peace and stability is the recruitment of national, universal and religious values, which will require improving the teaching of social sciences in higher education. To solve this complex and urgent task, a comprehensive analysis of the system of teaching social sciences in pedagogical higher education institutions.

It is important to widely apply the most advanced foreign methods, achievements in the field of educational literature and information communication.

In $n$ the era of globalization, it is urgent to pay more attention to national and religious values religion, purity, honesty, humanity, modesty, chastity and morality - in the fight against 
CURRENT RESEARCH JOURNAL OF PEDAGOGICS 2(9): 19-21, September

2021 DOI: https://doi.org/10.37547/pedagogics-crjp-02-09-04

ISSN 2767-3278

(C)2021 Master Journals

\section{Crossref do) 11 Google}

Accepted 15th September, 2021 \& Published 20 ${ }^{\text {th }}$ September, 2021

destructive "calls" to disrupt the minds of young people.

"Naturally, the idea of individualism, moral depravity and violence, which is the idea of egocentrism, as a culture and, conversely, a disregard for the original national and spiritual values, is a dangerous threat to today's development, human life, family sanctity and youth education"[2].

In order not to create a gap in the spiritual world of our youth, we need to instill in their hearts and minds a healthy lifestyle, respect and reverence for religious, national and universal values. In strengthening the sense of devotion to the motherland, young people are always required to be vigilant and vigilant, to warn them against the attacks of various destructive ideas. The role of the social sciences in warning young people of attacks of various destructive ideas and in providing appropriate protection is invaluable.

Indeed, "... educating young people in the spirit of patriotism, civic duty, tolerance, respect for laws, national and universal values, resilience to harmful influences and currents, strong beliefs and values in life, from violating the moral foundations of youth, protection from terrorism and religious extremism, separatism. fundamentalism, ideas of violence and cruelty; “ was identified as a priority [3].

As one of the solutions to these problems, it is necessary to increase the budget for the teaching of social sciences in the education of a harmoniously developed generation and to improve the system of teaching these subjects.

\section{ReFERENCES}

1. Decree of the President of the Republic of Uzbekistan No. PF 4947 of February 7, 2017 www.lex.uz
2. Alikhonov $M$. The issue of national pride among Uzbek intellectuals. - N.: Namangan, 2002. 1106 .

3. Law of the Republic of Uzbekistan No. ZRU406 of September 14, 2016 "On State Youth Policy". Www.lex.uz

4. Tashpulatovna T. A. The role of the older generation in protecting the modern youth from social dangers //European Journal of Molecular \& Clinical Medicine. - 2020. - T. 7. - №. 7. - C. 971-981

5. Turgunova A. GERONTOPEDAGOGYEDUCATION, Practice, Problems and Solutions //European Journal of Research and Reflection in Educational Sciences Vol. 2019. - T. 7. - №. 12.

6. Qaxxarova M., Absattorov B. M. Evolution of views on ethics, ethical criteria and ethical standards //The Light of Islam. - 2020. - T. 2020. - №. 1. - C. 110-115.

7. Kalandarova, D. U. (2020). Religion and social identity analysis in virtual space. ACADEMICIA: An International Multidisciplinary Research Journal, 10(10), 1164-1168

8. Kalandarova, D. (2020). Features of aspects of information exchange. The Light of Islam, 2020(1), 210-214.

9. Kahharova M. M., Holmirzaev H. D. UNDERSTANDING THE COLORS IN PHILOSOPHICAL AND PSYCHOLOGICALAESTHETIC WAY //НОВЫЙ УНИВЕРСИТЕТ. - 2014. - C. 52. 